\title{
Recall of MPs in the UK: 'If I Were You I Wouldn't Start from Here'
}

\section{David Judge}

\begin{abstract}
The publication of a White Paper, Recall of MPs, and a draft Bill for pre-legislative scrutiny, by the UK Government in December 2011 was greeted with almost universal antipathy. In bringing forward the draft Bill Cabinet Office ministers declared their intention to 'trigger a debate on what would be the best model for a recall mechanism' and they expressed a willingness 'to consider alternative models' or even to contemplate 'adopting a completely different approach'. Yet, they made it clear any such proposals 'must work within our unique constitutional framework' and be 'suitable for our system of representative democracy'. The objective of this article, therefore, is to do precisely what Cabinet Office ministers asked: to examine comparative experience and to apply lessons from that experience to the UK's 'unique constitutional framework'. Three questions guide the analysis: first, what is the problem to be addressed in introducing recall?; secondly, what does comparative experience reveal about the operation of recall? and thirdly how unique is the UK's constitutional framework?
\end{abstract}

The publication of a White Paper, Recall of MPs, and a draft Bill for pre-legislative scrutiny, by the UK Government in December 2011 (Cm 8241, 2011) was greeted with almost universal antipathy. Nearly every aspect of the draft Bill's provisions were subject to detailed, often scathing, criticism: from the trigger mechanism for recall petitions, through the conduct of the petition process, to the time lags and delays in the process (see HC 373, 2012). Proponents of recall were quick to dismiss the draft Bill as ' $180^{\circ}$ wrong. [It] is deeply and deliberately flawed' (Douglas Carswell, HC 373, 2012, ev q. 1); or as 'a pretence at recall [which] unless it is amended . . . needs to be rejected by those people who believe in true recall' (Zac Goldsmith, HC 373, 2012, ev q. 2); or to recommend that the Government should not introduce the Bill 'because it would be a waste of parliamentary time and, if anything, would increase the disconnect between voters and 
politicians, rather than closing the gap' (Peter Facey, HC 373 2012, ev q. 4). At least one academic expert on recall was similarly sceptical, with Anne Twomey concluding: 'I do not believe that the recall system proposed in the Bill will be likely to aid the restoration of public confidence in MPs and Parliament as a whole' (HC 373, 2012). Clearly, the message conveyed to Cabinet Office ministers in these responses to the draft Bill was 'if I were you I wouldn't start from here'.

With some prescience, in view of the reaction to the draft Bill, the Deputy Prime Minister, Nick Clegg and the Minister for Political and Constitutional Reform, Mark Harper, noted in the Foreward to the White Paper: "By its very nature, the subject of recall can be emotive and there will be divergent views on how we should proceed' ( $\mathrm{Cm} 8241,2011$, p. 5). In bringing forward the draft Bill, their declared intention was to 'trigger a debate on what would be the best model for a recall mechanism' and they expressed a willingness 'to consider alternative models' or even to contemplate 'adopting a completely different approach' (Cm 8241, 2011, para 157). Yet, they made it clear that any such proposals 'must work within our unique constitutional framework' and be 'suitable for our system of representative democracy' (Cm 8241, 2011, p. 5). The objective of this article, therefore, is to do precisely what Cabinet Office ministers asked: to examine comparative experience and to apply lessons from that experience to the UK's 'unique constitutional framework'.

Three questions will guide the analysis: first, what is the problem to be addressed in introducing recall?; secondly, what does comparative experience reveal about the operation of recall?; and thirdly how unique is the UK's constitutional framework? In answering these questions, this article contends that the coalition government's specification of the problem - the expenses scandal (and, by association, the more general and deep-rooted problem of public distrust of the parliamentary system) - did not necessarily mean that recall was the only, or indeed most viable option to deal with this problem. Indeed, two other options, discounted in the White Paper, arguably provided more logically coherent policy alternatives: one, for an enhanced internal expulsion procedure within the Commons, offered a closely delimited mechanism for dealing with infringements of MPs' conduct and standards; the other, for citizen-initiated recall, provided a more radical response to broader public disquiet about the activities of MPs. Yet, the fundamental argument of the article is that to reach a conclusion upon which, if any, of these options should be adopted requires consideration of a prior question: what is the role of an MP? 


\section{Where you start determines where you finish: identifying the problem}

An appropriate starting point for a discussion of the introduction of recall in the UK is perhaps the point of departure of the White Paper itself - the Cabinet Office's impact assessment (IA) (Cm 8241, 2011, pp. 51-9). The evidence base for this IA identified the MPs' expenses scandal of 2009 as the immediate trigger for the commitment to introduce a form of recall made by all three main political parties at the 2010 general election (Cm 8241, 2011, p. 55). By the time the IA was drafted, in September 2011, recall was presented as the only viable option. The 'base case' option - to do nothing - and continue with the existing arrangements had been automatically ruled-out as it did not fulfil the commitment for recall provision made in the Coalition's Programme for Government. This left one option according to the IA, a recall petition to be triggered: (i) automatically in cases where an MP had been given a custodial sentence of 12 months or less and (ii) under the discretion of the House where an MP had been found to have been engaged in 'serious wrongdoing'. Once a recall petition commenced, $10 \%$ or more of the constituents on the electoral register in the constituency would be required to sign the recall petition to initiate, automatically, a by-election. Notably, the IA did not consider two other options, both of which had been raised in the wake of concerns about the probity of MPs in 2008-2009. The first was enhancement of the existing Commons' procedures for the exclusion of MPs. The second was the introduction of citizen-initiated recall petitions.

\subsection{Option 1: effective exclusion}

Gordon Brown as Prime Minister in 2009 had identified 'effective exclusion' as a possible alternative to the status quo alongside 'recall for gross financial misconduct identified by a new independent regulator and the House itself '. In his statement to the House of Commons on 9 June 2009, it was clear that there were options in the plural: 'new proposals for dealing effectively with inappropriate behaviour, including the potential options of effective exclusion and recall for gross financial misconduct' (HC Debates, 10 June 2009, col. 796, emphasis added). He went on to repeat: 'We will modernise the means by which we deal with those issues where exclusion or recall is a possibility' (HC Debates, 10 June 2009, col. 803, emphasis added).

Indeed, the immediate parliamentary responses to the MPs' expenses scandal were targeted at dealing with 'the problem' of the expenses regime, the internal norms associated with that regime and the widespread belief, shared by the public and MPs alike, that self-regulation had been thoroughly discredited. 
In rapid succession, an Independent Parliamentary Standards Authority (IPSA) was established with a new scheme for MPs' allowances coming into effect in May 2010; a review of the Code of Conduct was initiated in the new parliament; and, as part of the 'recalibration' of the regulation of MPs activities to 'conform with public expectations' ( $\mathrm{Cm} 7224,2009$, para 13.67), the Committee on Standards in Public Life proposed in November 2009, and the House debated (in December 2010 and March 2012), and the Government accepted, the inclusion of at least two lay members on a newly constituted Standards Committee (see HC Debates, 12 March 2012, cols 69-84). The rationale behind all of these measures was to enhance 'public acceptance of the robustness and independence of the disciplinary process for Members of Parliament' $(\mathrm{Cm} 7724$, 2009, para 13.67).

These measures have, according to the Public Accounts Committee, resulted in a system for paying MPs expenses that is 'robust and has improved public confidence' (HC 1426, 2011, p. 5), and, according to Sir lan Kennedy the Chair of IPSA, there is a 'very significant sense that public money is now much better looked after than under the old system' (HC 1484, 2011, q. 257). The increase in public confidence was evident in the responses to an IPSOS MORI question commissioned by the National Audit Office in May 2011, which revealed that $55 \%$ of respondents believed that the situation with expenses had improved (HC 1273, 2011, p. 7). If the decline in public interest in the publication of MPs' claims is also taken as an indicator of diminished concern over such payments, then IPSA noted that interest had declined from 10,000 unique website hits in December 2010 (the first round of published claims) to 86 in July 2011 (HC 1426, 2011, ev. 19).

In terms of the changed profile of claims for expenses, the position was reached - within the first year of the introduction of the new scheme - that $99.7 \%$ of MPs' claims were within the scheme rules [with the remainder rejected primarily because of administrative errors or other oversights (HC 1426, 2011, p. 7)]. Indeed, the overall assessment of IPSA's Acting Accounting Officer was that '[MPs] are not attempting to game the system. By and large the claims are boring, and that is good' (HC 1426, 2011, q. 48). This 'regime change' was achieved without recall, and within the 'unique constitutional structure' noted in the White Paper. This is not to underplay the chafing of the new regime against some of the precepts of that structure (most notably on issues of parliamentary privilege), or the initial practical difficulties in administering the new scheme, but simply to note that the initial 'problem' of the old expenses regime had been addressed directly through legislation and through practical reviews post-2009.

If the problem to be addressed is conceived in terms of the regulation of MPs' financial probity and their conduct in the performance of their public duties, the 
cumulative changes noted above have gone some considerable way to mitigating the initial problem. The norms of the House have changed to the extent that conscious infringement of the new expenses regime is unlikely, and, consequently, the use of the disciplinary powers of the House to deal with such infringements is also less likely.

An alternative to recall, therefore, would be for the House to revisit the use of the expulsion procedure. Working from an investigation by the Parliamentary Commissioner for Standards and after consideration by the new Standards Committee, a motion to expel a Member would be moved. Depending upon the circumstances, and in accordance with established custom, a Member would be ordered to attend the House to offer an explanation. If the House accepts the motion the member would be expelled and a writ moved for a by-election. An expelled Member would be able to seek re-election to the House. The advantage of this option is that it simply revises and updates the historic disciplinary powers of the Commons and is nested within the established doctrine of parliamentary sovereignty. Indeed, further strengthening of the disciplinary procedures of the House, through an enhanced expulsion procedure, might be considered as a cost-effective and efficacious 'different approach' to recall which is compatible with the UK's 'unique constitutional framework'. Manifestly, this option would require MPs to explain and justify why this was a feasible option. Part of this explanation would undoubtedly have to entail affirmation from MPs that 'we are not all cheating, lying miscreants' and that the revised regulatory standards regime was judicious, effective and durable.

The bald statement in the White Paper that 'the House of Commons rarely uses the power to expel MPs' (Cm 8241, 2011, para 40) begs the question: why? One part of the answer is that an MP faced with the prospect of expulsion may choose to resign voluntarily (and certainly parliamentary parties have often sought to expedite that choice through withdrawal of the party whip). However, should an MP choose not to resign, the sanction of expulsion is still available to the House. In the recent case of Eric Illsey, ${ }^{1}$ for example, had he chosen not to resign - and to serve his sentence of 12 months while seeking to continue as an MP - the option was not that nothing could have been done in the absence of recall, but that the power of expulsion could have been invoked in this case (see Liam Laurence Smyth, HC 373, 2012, ev q. 114).

Another part of the answer may be found in the unwillingness of MPs to affirm, in the face of continuing public disaffection, their own capacity to deal objectively, fairly and decisively with the most 'serious wrongdoing' by their 
colleagues. More damningly ultimately, however, is an answer, advanced by some MP proponents of recall, which holds that: (i) votes in the House on an expulsion motion would be decided on the basis of party voting - either inter-party or intra-party (a 'settling of scores') or (ii) the Standards Committee, as 'Westminster grandees', would be either reluctant to recommend expulsion, or be too ready to do so in 'at the height of a media storm' (Carswell, HC 373, 2012, ev q. 8).

\subsection{Option 2: citizen-initiated recall}

In February 2008 the foreshock of the Conway case ${ }^{2}$ before the mainshock of the 2009 expenses earthquake, prompted 27 'freshmen' Conservative MPs to sign a letter making the case that: 'consideration should be given to creating a recall mechanism, similar to that used in some US states, to enable constituents to vote on whether they remove their MP during the course of a Parliament' (Daily Telegraph, 29 February 2008). This has been interpreted subsequently as a more open-ended commitment to the principle of recall than the option presented in the White Paper. It is worth noting, however, that the signatories stated: "We would want safeguards to be put in place to ensure that this mechanism was not abused, such as requiring a high percentage of registered voters in a constituency to petition for a recall ballot, or only permitting a recall ballot when the Commons Standards and Privileges Committee has recommended it as a sanction'.

The other option left unconsidered in the IA, therefore, was 'citizen-initiated recall': a mechanism that enables constituents to remove their MP in between elections, without limitation to 'serious wrongdoing'. In October 2009, Douglas Carswell introduced a Ten Minute Rule Bill to this end, and in September 2010 Zac Goldsmith introduced his Presentation Bill, Recall of Elected Representatives Bill, which would have permitted voters to recall their representatives if they had: '(i) acted in a way which is financially dishonest or disreputable, (ii) intentionally misled the body to which he or she was elected, (iii) broken any promises made by him or her in an election address, (iv) behaved in a way that is likely to bring his or her office into disrepute or (v) lost the confidence of his or her electorate'. Not surprisingly, Carswell and Goldsmith were not only two of the most ardent advocates of citizen-initiated recall but also two of the most vehement critics of the draft Bill (for an exposition of their views see $\mathrm{HC} 373$, 2012, ev q. 1-53). 


\section{The appropriateness of comparator models}

As noted above, the Cabinet Office in drafting its White Paper claimed both to have 'drawn upon the experiences of other countries' (Cm 8241, 2011, p. 5) and to have 'learn[ed] lessons from the recall mechanisms that already exist elsewhere' (Cm 8241, 2011, para 158). Thus, a listing was provided of the main models for the recall of individual representatives found in the USA, Canada, the Philippines and Venezuela. Recall provisions were not considered for collective recall elections of legislatures in Switzerland (Canton), Germany (in six Länder), Lichtenstein, Japan (local government assemblies) or for proposals for the introduction of recall for the State Legislative Assembly in New South Wales, Australia (for details of these models see Jackson et al., 2011, pp. 28-57).

Most of the models of recall for individual representatives were summarily dismissed as comparators in the White Paper because they allowed for a politician 'to be recalled for "political" reasons' and thus infringed the Government's commitment to introduce recall only where MPs' conduct 'falls below the standards expected of those who hold public office' ( $\mathrm{Cm} 8241,2011$, para 23). The belief that 'it is our view that no model can simply be imported', and that what was needed was a 'bespoke recall mechanism which we believe best fits our model of representative democracy', would appear to have precluded from the outset the meaningful consideration of other models.

Yet it is worth examining other models to gain an understanding of: how political and social context influenced the adoption of recall procedures in other states; the problems that recall elections were designed to address and the subsequent ramifications of recall elections for representative processes. Such an understanding provides a comparative frame within which to assess proposals for the recall of MPs in the UK. In the following section, the comparator countries are 'Anglo-American' democracies of the USA and Canada.

\subsection{Problem addressed by the introduction of recall}

2.1.1 Recall in the USA There are no recall provisions at a federal level in the USA (see Maskell, 2012). Nineteen state constitutions allow for recall of state officials and 29 allow for the recall of local officials (NCSL, 2011). Eight states require specific grounds to be stated on a recall petition, with these often encompassing 'malfeasance, misfeasance' (New Mexico, Florida, Washington) or 'misconduct, malfeasance, nonfeasance' (South Dakota). In the other 11 states, recall can be sought on any grounds.

The basic problem to be addressed through recall elections was the perception in the early 20th century (when the first wave of recall elections were included in state constitutions) that 'state capitols and city halls [were] infested with the 
privileged, the sinister and the corrupt' (Cronin, 1989, p. 130). In other words, recall in the USA had its origins 'in a notably corrupt political system' (Cronin, 1989, p. 131; Pack, 2008, p. 692). At that time, the progressive movement was influential in challenging the control of party bosses and political machines and the excessive political influence wielded by a few large corporations in the newly industrialised USA. Less remarked upon, but equally significant in the discussion of recall, was the Progressive's 'deep contempt for legislatures in general' (Persily, 1997, p. 25) which in the long run did much to institutionalise a suspicion of legislatures and representative politics more generally (Persily, 1997, p. 37). The inaugural address of Hiram Johnson as Governor of California in 1911 not only made explicit the connection between corruption, governmental 'inefficiency' and the need for recall, but also provided what was to become a classic justification of recall:

Those of us who espouse [this measure] do so because of our deep-rooted belief in popular government, and not only in the right of the people to govern, but in their ability to govern; and this leads us logically to the belief that if the people have the right, the ability, and the intelligence to elect, they have as well the right, ability, and intelligence to reject or to recall (Johnson, 1911)

Obviously, a more nuanced examination of the origins of recall in the USA would need to include recognition of other explanatory variables beyond the ideologies of 'progressive politics' (see Persily, 1997; Ware, 2002; Pack, 2008). These would include the temporal sequencing of the adoption of state constitutions, the geo-political divergences across US states in the early 20th century (which encompassed changed dynamics of interest group and party politics within states), and distinct processes of party institutionalisation. Nonetheless, it is worth bearing in mind the broad political context of the introduction of recall in the USA, as well as remembering that recall was often only one part, and often the most contentious part, of a triptych of reforms - of the initiative, referendum and recall (Weinstein, 2005, p. 133).

This triptych relationship may explain in part the reason why recall at a state level has been relatively little used: if policy disjunction between representative and represented is the source of contention then an initiative or a referendum on a particular policy may be more efficacious and efficient (with lower trigger thresholds) in addressing the issue than recall. Indeed, it has been speculated that the adoption of a recall mechanism in isolation may give rise to more recalls in other countries than has been the case in the USA (Jackson et al., 2011, p. 40).

2.1.2 Recall in Canada: British Columbia The introduction of recall in British Columbia's Recall and Initiative Act 1995 has been explained as a response to 
rising public alienation from the parliamentary system (Ruff, 1996, p. 101). The background explanatory factors accounting for the adoption of recall included a strong 'populist culture', a potent mix of political scandals, combined with party electoral manoeuvring and bidding before the 1991 election (that saw the introduction of the 1990 Referendum Act and the promise of the ruling Social Credit Party to place on the election agenda the extension of citizens' participation, through the introduction of initiatives and recall).

In this sense the background to the introduction of recall in British Columbia is perhaps most analogous to the context of the UK. Moreover, the constitutional DNA of British Columbia has interwoven within it genetic strands of the Westminster model. British Columbia differs significantly from the UK, however, in drawing upon a pronounced, historically rooted populist political tradition (see Elkins, 1985, pp. 61-72; Ruff, 1996, p. 99). This has found reflection not only in the introduction of the citizens' initiative, referendum and recall, but also in the British Columbia Citizens' Assembly of 2004.

\section{What does comparative experience tell us?}

\subsection{Sub-national usage}

As noted above, there is no constitutional provision for recall elections at a US federal level. In the 19 states that allow for state-wide recall elections, up until 2011 , only two state governors and 21 state legislators had been recalled.

Recalls are most frequent at a local level, and at that level recalls serve as a powerful accountability mechanism in a context of: (i) often personalised, low-intensity or non-, partisan elections, (ii) low voter turnout, (iii) occasionally maverick incumbents and (iv) the absence, or ineffectiveness, of alternative formal mechanisms of control, such as monitoring agencies or informal accountability mechanisms, such as intra-party discipline. In these circumstances, inter-election direct accountability through recall - of representatives performing often functionally specific tasks, for example school board members, sheriffs, soil and water conservation supervisors, etc. - has an immediate logic. As Orr opines: 'Recall elections fit a US-style, candidate centred politics'. In systems 'rooted in Westminster forms and traditions', however, he believes that they are 'inadvisable' (Orr, 2011, p. 1).

\subsection{Infrequent use?}

In 1989 Cronin concluded that 'Because of relatively infrequent use the recall has not usually been a disruptive factor in representative government' (Cronin, 1989, p. 145). Bowler (2004, p. 208) later estimated that $95-97 \%$ of incumbents at a 
local level in the USA were safe from recall. Indeed, historically the combination of initiative, referendum and recall in US state constitutions served to limit the number of recalls, if for no other reason than because it was easier to prompt action, or redress divergent policy preferences between the represented and their elected representatives through initiative or referendum.

But the historical pattern of infrequent recalls unravelled in 2011 when over 150 elected officials faced recall votes in 17 states (84 of whom lost their seats). Since the adoption of recall in 1908, 32 state legislators have faced recall: seven in the period 1908-1980, 14 between 1981 and 2009 and 11 recall votes in the single year of 2011 (Spivak, 2011). In 2012 Wisconsin Governor Scot Walker became only the third Governor to face a recall vote. As Spivak (2011) concludes: 'the growth of recall is a long-developing trend. Don't expect it to disappear anytime soon'. Even so the number of recalls, as a proportion of office holders potentially subject to recall provisions, remains notably small.

\subsection{Organised publics: parties and groups}

Whereas, in the discourse of supporters of citizen-initiated recall, 'the public', 'the people' or 'the constituents' are often conceived as aggregations of atomised, independently rational individuals, the reality of political life in representative democracies is that the 'general public' remains unorganised and 'specific publics' become organised into, variously, political parties, interest groups, NGOs and social movements. Moreover, it should also be noted that sections of the media seek to play a significant role in 'organising' the so-called 'public opinion'.

The Wisconsin case is particularly instructive because it reveals that although recall is a mechanism directed at individual representatives, multiple simultaneous elections can have a cumulative and collective effect upon both the composition and the policies of a legislature. More specifically, although a recall petition names an individual representative, the recall campaign may be contested on the grounds of wider partisan or organised interest politics. Thus, in Wisconsin in 2011 an initial wave of recall petitions against eight Democratic Senators (three of which triggered recall elections, but with all Democratic Senators retaining their seats) led in turn to the Democratic Party and labour unions targeting eight key Republican Senators (triggering six recall elections). The choice of Republicans was both 'purposeful' (Jackson et al., 2011, p. 20) for the offices held, but also reflected wider national electoral considerations. 'In a way, these recall elections ... grew out of a different election' (Davey, 2011). In one direction they harped back to the 2010 elections, and to redressing the gains made by Republicans, and in the other they looked forward to the 2012 presidential election and presaged national debates. Whichever direction was surveyed, the 
evidence pointed to the use of recall for party political purposes - and increasingly so in a polarised polity (Gilbert, 2011). This polarisation was underscored with the recall petitions launched in 2012 against the Republican Governor Scott Walker, the Lieutenant Governor and four other Republican state senators. Indeed, as Jackson et al. (2011, p. 22) note, 'the Wisconsin experience demonstrates that recall elections can become "normalised", and become part of the "standard tool-kit of political conflict", rather than an "extraordinary measure"'.

In British Columbia, since the first use of recall in 1997, 24 recall petitions have been launched, only two of which secured sufficient signatories to proceed to the verification stage. ${ }^{3}$ Between 2003 and 2010 no recall petitions were launched. This has led to the conclusion that: "It would seem . . . that the difficulty of obtaining recall in British Columbia has meant that potential tensions with the broader understanding of a member's role in a Westminster system have not crystallised' (Jackson et al., 2011, p. 58). Yet the recent 2010-2011 campaign against the harmonised sales tax (HST) revealed just such tensions when the 1995 Recall and Initiative Act was used to register an HST Extinguishment Act as a citizen initiative. Accompanying this initiative, a recall campaign was launched to remove Members of the Legislative Assembly (MLA) one by one, in an attempt to prompt the government to repeal the tax or be threatened with the possibility of losing its nine-seat majority. Ujjal Dosanjh, Liberal MP until the federal election in 2011 and former BC premier, expressed concern that the anti-HST campaign misused the recall provisions: 'the recall legislation was not meant to cause an overthrow of government because you disagree with the public policy of that government'. With the decision to abolish the HST in August 2011, the recall campaigns fizzled out (after a referendum vote to abolish the tax - even though the $55 \%$ majority did not meet the 1995 Act's threshold of $50 \%$ support of all registered voters).

While the lessons for the UK are not necessarily directly transposable, nonetheless, the recent experience of recall in Wisconsin and British Columbia points to the potential of citizen-initiated recall being used for collective, partisan purposes. Specifically, the example of Wisconsin reveals that, as a result of recall elections and their associated effects, a Republican Senate majority of 19-14 after the 2010 state elections was eroded to a 16-16 party balance by March 2012, even before the second wave of recall elections held later in 2012. Clearly, the targeting of individual representatives with the objective of cumulatively affecting the aggregate composition of the legislature - to the detriment of the majority party or governing coalition parties - would have immediate resonance for the UK should 
political executives in the near future come to be characterised by small majorities, or to act as minority or coalition governments. Moreover, in a five-year fixed-term parliament, opposition forces (whether parties or social movements) might be tempted to chip away at government majorities, or the internal balance of parties within coalitions, through targeted recalls in marginal constituencies.

\subsection{Effect of recall petitions on recallees}

The experience of representatives who have been subject to recall campaigns is worthy of note. Tom Cochrane, CEO of the USA Conference of Mayors, noted in the face of what he called 'recall fever': 'Most mayors survive recall elections, but the effort drains them of time and energy better focused on problems facing their cities' (Cochrane, 2011). Similarly, in British Columbia, one former MLA and then cabinet minister, who had been subject to a recall petition in the late-1990s, noted during the anti-HST campaign: 'The reality is you are trying to be an MLA and a cabinet minister, while fighting an extended election campaign' (cited in Mickleburgh, 2010). And one of the targeted representatives for recall in the anti-HST campaign, Ida Chong, reflected upon her experience: 'You can work hard as an MLA. You can think people are paying attention to the good things you're doing. But if you don't communicate and share the good work, people don't know - and that works against you' (cited in Slavin, 2011).

\subsection{Ambivalences and ambiguities in the conception of representation}

One of the more uncomfortable aspects of the recall process is not so much how it unsettles politicians, but how it exposes vagueness in our definitions of representation (Bowler, 2004, p. 211)

Bowler's study of recall in California highlighted the close connection between the practical arguments used, respectively, by proponents and opponents of recall and abstract models of representation. On the one side, the major argument deployed by proponents of recall corresponded to 'an extreme form of the delegate model of representation', while the argument against the use of recall elections was 'grounded in a preference for a trustee model of representation' (Bowler, 2004, p. 204). Yet, Bowler proceeded to note that the 'actual practice of representation, occupies a muddy middle ground where representatives follow voter opinions sometimes but sometimes do not' (Bowler, 2004, p. 212). In these circumstances, the practical use of recall posed elemental questions for normative ideas of representation: about the role of representatives and their pivotal position between 'governors' and 'governed' alike. 
If a system of citizen-initiated recall were to be contemplated in the UK with few, or no, restrictions as to trigger, such as in Zac Goldsmith's Bill, then the ambivalences and ambiguities of representation in the UK would rapidly manifest themselves. Not least, the fundamental questions: what exactly do MPs 'do', or what do their constituents expect them to do, and for which actions do constituents expect their MPs to be held accountable? The fact that there are multiple theories of representation prescribing what an MP should do, which exist in parallel and which influence MPs' own behaviour and citizen expectations, combined with the fact that there is no accepted job description for MPs, means that idealised models of representation couched in terms of principal-agent relationships, or idealised job descriptors, fail to capture even the normative complexity of what MPs 'should do'.

Stated at its simplest, conflicting representative theories have coexisted, often uneasily, in the UK and impacted upon the performance of MPs' roles in Westminster (Judge, 1999). In this sense, the practice of representation is far from unidimensional, and the adherence to contrasting principles of representation leads to an ambivalence in the interpretation of the representative's role. This is apparent in recent academic studies (most recently in Rush and Giddings, 2011, pp. 104-34), as well as in public attitudes (see Committee on Standards in Public Life, 2011, pp. 29-35).

The fact that there is no formally accepted job description for the work of an MP was recognised, by the Speaker's Conference on Representation in 2010, as a source of 'misunderstanding' and 'unrealistic expectations' on the part of voters in the constituency (HC 239-I, 2010, para 85). To date an agreed description of the main functions of an MP has not been produced by the main parties, as recommended by the Speaker's Conference. An earlier attempt at identifying 'a number of commonly recognised tasks' performed by MPs had been made by the House of Commons Modernisation Committee (HC 337, 2007, para 10). In identifying six common tasks the Committee concluded that: 'The different roles that make up the job of being a Member of Parliament are not separate and competing; they are interconnected and interdependent' (HC 337, 2007, para 11). This very interconnectedness has implications for citizen-initiated recall: MPs 'supporting their party in votes in parliament' (task 1) may very well conflict with 'representing and furthering the interests of their constituency' (task 2) and 'representing individual constituents and taking up their problems and grievances' (task 3), and also inhibit their capacity of 'initiating, reviewing and amending legislation' (task 5).

Recall is based upon a conception of a representative acting as an individual (with a personal vote) for a specific locality (constituency focus), whereas the prevailing practice of representation in Westminster is primarily collective (party based) and statal (national focus). So too is the practice of voting. Although 
incumbent MPs seek to enhance their electoral prospects, particularly in marginal seats, through cultivating a 'personal vote', and although this strategy has had some limited effect in recent elections (see Curtice et al., 2010, p. 395), it still remains the case that valence politics - assessments of a party leader's image or perceptions of a party's economic competence or party identification - continue to be the most powerful variables in explaining voting behaviour (Clarke et al., 2012, pp. 117-33).

The significance of this is: if there is neither a simple single conception of what MPs should do, nor agreement upon what they actually do, it is extremely difficult to determine what they are responsible for, in the sense of individual culpability (beyond personal malfeasance or misfeasance), and the grounds upon which they should be recalled.

The complexity of the performance of representative roles in Westminster is perhaps not surprisingly a source of confusion for many voters. The 2011 Audit of Political Engagement revealed that 'views on whether or not participants felt represented by their MP very much relied on knowledge of who their MP was' (Hansard Society, 2011, p. 32). Even at this most basic level of knowledge only $38 \%$ of respondents were able to name their MP correctly (Hansard Society, 2011 , p. 63). Admittedly, the fact that the survey was conducted only six months after the 2010 election, after a high turnover of MPs, might have reduced name recognition, but even at its height in earlier surveys only $44 \%$ of respondents had been able to name their MP (Hansard Society, 2011, p. 63). The significance of this finding for a discussion of recall is that many of the participants who did not know their MP's name proceeded to extrapolate that their MP 'must not be doing a good job of representing them because, if they did not even know who he or she was, how could they be doing so?' (Hansard Society, 2011, p. 32). Equally, participants struggled to reconcile their pronounced view of MPs as representatives of their constituents with the strongly held view of the importance of a party's mandate and the expectation that party MPs would be expected to support that mandate through the course of a Parliament (Hansard Society, 2011, p. 32). As the report noted, these views clearly ran counter to each other (Hansard Society, 2011, p. 32).

\section{The uniqueness of the UK: parliamentary sovereignty as an inhibitor of the adoption of citizen-initiated recall?}

In the White Paper, the Government placed great emphasis upon the UK Parliament's sovereignty, its 'exclusive cognisance over its internal affairs' and its 'role in holding the executive to account' (Cm 8241, 2011, para 21). In so doing, the Government claimed to have 'created a new model that we believe best fits our system of representative democracy' (Cm 8241, 2011, para 157). 
Whereas the Government started from the premise that the UK's 'unique constitutional framework' (Cm 8241, 2011, para 5) provided firm democratic foundations, supporters of citizen-initiated recall identified that very framework as inimical to securing enhanced accountability of MPs to their electorates. Without rehearsing such criticisms in detail here, their essence is that representative government in the UK, historically, has been conceived and functioned as a means of legitimating executive power (see Judge, 1993). An executive centric state has been justified in terms of a legislative-centric theory of parliamentary sovereignty. The practical pre-eminence of the executive in the UK state has thus been founded upon the theoretical 'pre-eminence of the House of Commons'. This has been the central paradox of the parliamentary state (see Judge, 1993, 2006, pp. 373-5; Flinders, 2010a, pp. 224-5).

It needs to be remembered, however, that the normative political claims associated with parliamentary sovereignty are different from the legal claims of the doctrine. The political claims have accommodated significant recalibrations of the UK's constitution - membership of the European Union, devolution, the Human Rights Act and the European Union Act 2011 - while keeping intact the formal legal claims that Parliament cannot bind its successors and that the UK Parliament can ultimately repeal the legislative acts sanctioning these constitutional changes. In other words, to assert the uniqueness of the UK's constitution is as much a political claim as a constitutional claim: and does not necessarily, or obviously, preclude the enhancement of participatory processes (as already demonstrated in the introduction of e-petitions, party primaries, citizens' juries, referendums, etc.). Whether these processes are allowed to flourish is equally a political question - of whether the executive is prepared to self-limit its legislative pre-eminence.

Indeed, there is a growing academic debate about the 'hybridisation of democracy' in western representative democracies that has resonance for the UK Government in its defence of 'parliamentary sovereignty' and its belief in the 'uniqueness' of the UK's constitutional framework. In the USA, Garrett (2006, p. 227) has long argued that, for the vast majority of Americans, 'government is a hybrid democracy - a combination of direct democracy and representative institutions'. More recently, and more pertinently for the UK, Hendriks and Karsten (2011, p. 11) have argued that 'there appears to be an empirical trend towards hybridisation of democracies throughout Europe'; a trend which is illustrated in Hendriks and Michels' (2011) specific comparative study of constitutional change in the UK and the Netherlands over the two decades prior to 2010. The introduction of democratic innovations within this period served to 'stretch' established models of representative democracy in order to accommodate such changes. In the UK, as noted above, successive governments have demonstrated a pragmatic willingness to 'stretch' existing constitutional precepts 
through participatory innovations, while simultaneously seeking to constrict the extent of 'stretch' within the bounds of 'parliamentary sovereignty'. Yet, concurrently, these boundaries are also being frayed by arguments that the doctrine of parliamentary sovereignty is not 'a unique legal arrangement without parallels in comparative constitutional law' (Eleftheriadis, 2009), and that it is 'no longer the governing principle of the British constitution' (Bogdanor, 2009, p. 283; 2012, pp. 194-195). In which case the Government's case is founded upon an implicit political claim of the advantages of majoritarian government, and the skewed relationship between executive and the legislature that results from that form of government, as much as an agreed legal claim about the sanctity of 'parliamentary sovereignty'.

\section{Conclusion: where you finish depends on where you start}

At one level the restricted nature of the draft Bill is entirely defensible in terms of the manifesto pledges of the coalition partners, the commitment made in the Programme for Government and the Government's formalistic conception of 'parliamentary sovereignty'. In this direct sense the Bill aims to redress the problem of 'the behaviour of individual MPs which rocked confidence in Parliament over the expenses scandal' (Cm 8241, 2011, p. 5). Thus, at this level, the starting point of the draft Bill can be seen as an attempt to sweep up the remaining debris from the earthquake of the expenses scandal. Even within the restrictive logic of the draft Bill, however, a number of factors - the constricted trigger mechanisms, exclusionary processes for recording petition signatures, and the moral and political and contortions that would confront MPs in deciding what constituted 'serious wrongdoing' sufficient to trigger recall - all point to the conclusion that implementation of the Bill would be likely to generate more problems than it would solve (for a detailed critique see HC 373, 2012).

Indeed, if the problem to be addressed is 'serious wrongdoing' (of the type associated with the old expenses regime) then the changes to, and greater regulation of, the expenses regime since 2009 , and the institutional bolstering of 'standards' more generally, have severely curtailed the opportunities for serious transgression of the new rules. When this is taken in conjunction with the extremely low numbers of MPs (aside from those embroiled in the expenses crisis) who have received custodial sentences, or been sanctioned under the House's rules for what might be identified as 'serious wrongdoing', then it is a reasonable expectation that the recall provisions of the draft Bill would be invoked only exceptionally. Indeed, in the words of Spivak (2012), MPs would have to have done something 'breathtakingly wrong' to be subject to recall under the Government's proposals. In which case further strengthening of the disciplinary procedures of the House, through an enhanced expulsion procedure, might be 
considered as a cost-effective and efficacious option within the UK's 'unique constitutional framework'. As noted above, this option would require MPs to explain and justify why this was a feasible option. Such a positive affirmation of the value of being an MP, by MPs themselves, would chime with the defence of representative politics, and politicians, recently advanced in the UK by Peter Riddell (2010, 2011) and Matt Flinders (2010b, 2012).

However, if this affirmation were to be rejected by the public, given the depths of public cynicism, then the introduction of citizen-initiated recall - as part of a wider reformist participatory package - would be the preferred option of many critics of the draft Bill. Indeed, part of the hostility of supporters of citizen-initiated recall to the draft Bill was precisely that its restricted remit would deflate expectations, raised by the responsible Cabinet Office Minister himself in launching the While Paper, of 'rebuilding trust in politics, [and] ensuring that politicians are properly accountable to the people they represent' (Mark Harper, HC Debates, 13 December 2011, col.91WS). If the point of departure were, thus, to be identified as ensuring 'proper' accountability - beyond 'serious wrongdoing' then citizen-initiated recall would be one logical legislative 'end point'.

In turn, if the option of citizen-initiated recall was to be adopted, it would bring to the fore the problems and issues already apparent in other states that operate recall elections. These problems cannot be wished away. Indeed, in confronting these problems the 'uncomfortable aspects of the recall process ... in expos[ing] vagueness in our definitions of representation' would be exposed, along with a need to recognise the 'paradoxes of the parliamentary state' including a need to answer the conjoined practical and theoretical question of 'what do we expect of our MPs'? Thus, if the introduction of citizen-initiated recall is taken as a legislative 'end point', in turn, and paradoxically, it circles back to the need for a different 'starting point' - of a prior public debate (and educational campaign) about 'what MPs do' or 'what they should do'. In this case, where you finish requires a re-examination of where you start.

\section{Notes}

1 In January 2011, Eric Illsley was found guilty of false accounting, and subsequently received a custodial sentence of 12 months. At the time of his conviction he was still an MP, but he chose to resign his seat before he was sentenced to prison.

2 In January 2008 Derek Conway was suspended from the House for 10 days after the Select Committee on Standards and Privileges found that there had been a serious breach of the House's rules in relation to the employment of one of his sons.

3 Once called, if at least $40 \%$ of registered electors in the MLA's constituency (at the time of the last election) support the petition then a by-election is automatically held to fill the seat of the recalled member. The recalled MLA may run in this by-election.

\section{References}

Bogdanor, V. (2009) The New British Constitution, Oxford, Hart Publishing. 
Bogdanor, V. (2012) 'Imprisoned by a Doctrine: The Modern Defence of Parliamentary Sovereignty', Oxford Journal of Legal Studies, 32, 179-195.

Bowler, S. (2004) 'Recall and Representation: Arnold Schwarzenegger Meets Edmund Burke', Representation, 40, 200-212.

Clarke, H., Sanders, D., Stewart, M. and Whiteley, P. (2012) 'Valence Politics and Electoral Choice in Britain, 2010'. In Fisher, J. and Wlezien, C. (eds.) The UK General Election of2010: Explaining the Outcome, London, Routledge. Cm 7224 (2009) 'MPs' Expenses and Allowances', Twelfth Report, Committee on Standards in Public Life, London, Stationery Office.

Cm 8241 (2011) Recall of MPs Draft Bill, London, Stationery Office.

Cochrane, T. (2011, May 10) 'Recall Elections Waste Public Funds and Cause Chaos', US News, accessed at http://www.usnews.com/opinion/articles/2011/05/10/recallelectionswaste-public-funds-and-cause-chaos on January 11, 2012.

Committee on Standards in Public Life (2011) Survey of Public Attitudes Towards Conduct in Public Life 2010, London, Committee on Standards in Public Life.

Cronin, T. E. (1989) Direct Democracy: The Politics of Initiative, Referendum, and Recall, Cambridge, MA, Harvard University Press.

Curtice, J., Fisher, S. and Ford, R. (2010) 'An Analysis of the Results'. In Kavanagh, D. and Cowley, P. (eds) The British General Election of 2010, Houndmills, Palgrave Macmillan.

Davey, M. (2011, August 10) 'In Wisconsin, a Big Recall Push Comes Up Short', New York Times, accessed at http://www.nytimes.com/2011/08/11/us/politics/11 wisconsin. html? r=2 on January 24, 2012.

Eleftheriadis, P. (2009) 'Parliamentary Sovereignty and the Constitution', Canadian Journal of Law and Jurisprudence, 22, 267-290.

Elkins, D. J. (1985) 'British Columbia as a State of Mind'. In Blake, D. E., Elkins, D. J. and Johnson, R. (eds) Two Political Worlds: Parties and Voting in British Columbia, Vancouver, University of British Columbia Press.

Flinders, M. (2010a) Democratic Drift, Oxford, Oxford University Press.

Flinders, M. (2010b) 'In Defence of Politics', Political Quarterly, 81, 309-326.

Flinders, M. (2012) Defending Politics: Why Democracy Matters in the 21st Century, Oxford, Oxford University Press.

Garrett, E. (2006) 'The Promise and Perils of Hybrid Democracy', Oklahoma Law Review, $59,227-270$.

Gilbert, C. (2011, March 12) 'State Recall Movement Stands Alone in US History', Journal Sentinel, accessed at http://www.jsonline.com/blogs/news/117804138.html on January $11,2012$.

Hansard Society (2011) 'Audit of Political Engagement 8: The 2011 Report', London, Hansard Society.

HC 337 (2007) 'Revitalising the Chamber: The Role of the Backbench Member', First Report Session 2006-07, Committee on Modernisation, London, Stationery Office.

HC 239-I (2010) 'Speaker's Conference (on Parliamentary Representation)', Final Report, House of Commons, London, Stationery Office.

HC 1273 (2011) 'Independent Parliamentary Standards Authority: The Payment of MPs' Expenses', Report by the Comptroller and Auditor General, London, Stationery Office. 
HC 1426 (2011) 'Independent Parliamentary Standards Authority', 51st Report Session 2010-12, Committee of Public Accounts, London, Stationery Office.

HC 1484 (2011) 'The Operation of the Parliamentary Standards Act 2009', First Report Session 2010-12, Committee of Members' Expenses, London, Stationery Office.

HC 373 (2012) 'Recall of MPs', Report Session 2012-13, Committee on Political and Constitutional Reform, House of Commons, London, Stationery Office.

Hendriks, F. and Karsten, N. (2011) 'Democratic Theory and the 'Anomaly' of Leadership', SSRN Working Paper Series, accessed at http://papers.ssrn.com/sol3/papers.cfm? abstract_id=1972874 on January 23, 2012.

Hendriks, F. and Michels, A. (2011) 'Democracy Transformed? Reforms in Britain and the Netherlands (1990-2010)', International Journal of Public Administration, 34, 307-317.

Jackson, D., Thompson, E. andWilliams, G. (2011) 'Recall Elections for New South Wales? Report of the Panel of Constitutional Experts', Sydney, NSW Department of Premier and Cabinet.

Johnson, H. (1911) 'First Inaugural Address', delivered 3 January 1911, accessed at http:// governors.library.ca.gov/addresses/23-hjohnson01.html on January 11, 2012.

Judge, D. (1993) The Parliamentary State, London, Sage.

Judge, D. (1999) Representation: Theory and Practice in Britain, London, Routledge.

Judge, D. (2006) "This is What Democracy Looks Like": New Labour's Blind Spot and Peripheral Vision', British Politics, 1, 367-396.

Maskell, J. (2012) 'Recall of Legislators and the Removal of Members of Congress from Office', CRS Report for Congress, Washington, DC, Congressional Research Service.

Mickleburgh, R. (2010, September 20) 'B.C. HST Foes Launch Drive to Vote Liberals "Off the Island"', Globe and Mail, accessed at http://www.theglobeandmail.com/news/ national/british-columbia/fight-hst-launches-bc-recall-campaign/article1715074/ on January 18, 2012.

NCSL (2011) 'Recall of State Officials', Denver, National Conference of State Legislators, accessed at http://www.ncsl.org/legislatures-elections/elections-campaigns/recallofstate- officials.aspx on January 16, 2012.

Orr, G. (2011) 'Submission from Graeme Orr, Panel of Constitutional Experts - Recall Election Inquiry', accessed at http://www.dpc.nsw.gov.au/_data/assets/pdf_file/ 0014/131126/15_Dr_Orr.pdf on January 11, 2012.

Pack, T. (2008) 'High Crimes and Misdemeanors: Removing Public Officials from Office in Utah and the Case for Recall', Utah Law Review, 2008, 665-696.

Persily, N. A. (1997) 'The Peculiar Geography of Direct Democracy: Why the Initiative, Referendum and Recall Developed in the American West', Michigan Law and Policy Review, 2, 11-41.

Riddell, P. (2010) 'In Defence of Politicians: In Spite of Themselves', Parliamentary Affairs, $63,545-557$. 
Riddell, P. (2011) In Defence of Politicians: In Spite of Themselves, London, Biteback Publishing.

Ruff, N. (1996) 'The British Columbia Legislature and Parliamentary Framework'. In Carty, R. K. (ed.) Politics, Policy and Government in British Columbia, Vancouver, University of British Columbia Press, pp. 85-102.

Rush, M. and Giddings, P. (2011) Parliamentary Socialisation: Learning The Ropes or Determining Behaviour, Houndmills, Palgrave Macmillan.

Slavin, K. (2011, December 23) 'Chong Reflects on 'Volatile' 2011', Saanichnews, accessed at http://www.saanichnews.com/news/136159808.html on January 16, 2012.

Spivak, J. (2011, December 27) '2011: The Year of the Recall Election', Los Angeles Times, accessed at http://articles.latimes.com/2011/dec/27/opinion/la-oe-spivak-recall20111227 on January 9, 2012.

Spivak, J. (2012, January 6) 'A Recall Law - The New Must-Have Tool for Voters', Total Politics, accessed at http://www.totalpolitics.com/blog/287332/a-recall-law-thenewmusthave- tool-for-voters.thtml on January 9, 2012.

Ware, A. (2002) The American Direct Primary: Party Institutionalization and Transformation in the North, Cambridge, Cambridge University Press.

Weinstein, R. (2005) 'You're Fired! The Voters' Version of the 'Apprentice': An Analysis of the Local Recall Elections in California', Southern California Interdisciplinary Law Journal, 15, 131-163. 